\title{
Applications of Ultrafiltration, Reverse Osmosis, Nanofiltration, and Microfiltration in Dairy and Food Industry
}

\author{
Jasper Shekin J \\ College of Dairy Science and Technology, Ludhiana, Punjab, India \\ Corresponding author email: jaspershekin@ outlook.com \\ Received: 20 October 2021 / Accepted: 09 December 2021 / Published: 10 December 2021

\begin{abstract}
Food industry is the place to convert raw edible materials to processed foods. Processing foods involves standardization, removal of unnecessary components, addition of essential components, thermal treatments etc. Membrane processes help enhancing the food primely in terms of keeping quality, nutritional value, component recovery and by-products utilization. Feed is given to the membrane system while retentate and permeate are obtained. Components of food can be separated according to size, charge and other characteristics using various membrane processes. The major ones are Ultrafiltration, Reverse Osmosis, Nanofiltration and Microfiltration which are done either single or in combination of more than one process and also in addition with processes such as electrodialysis and vacuum membrane distillation. These processes act as step $(\mathrm{s})$ in the operating procedure of a food or as an alternative method to process the same food with better quality.
\end{abstract}

Keywords: Membrane Technology, Dairy Processing, Food Technology.

\section{Introduction}

The word membrane is derived from the Latin word 'membrana', meaning skin. A membrane can be defined as the selective barrier which separates two phases and inhibits transit of various chemicals in a selective manner. Membranes are semi-permeable in nature, which means that they allow certain particles to flow through while excluding others. The properties include size, charge etc. Different membrane processes have different selectivity when it comes to allowing or disallowing particles or dissolved molecules in the solution. Membrane filtration uses the separation capabilities of finely porous polymeric or inorganic films to perform improved filtration. Separation of biological macromolecules, colloids, ions, solvents, and gases is accomplished using these methods. It takes knowledge of the physical properties of the solution to be separated to select and develop an appropriate membrane technique in a separation.

The membrane processes had their industrial applications from 1960s, while several laboratory studies were carried out since 1748, when the membrane phenomenon 'osmosis' was accidentally discovered by Abbe Nollet. He observed the stronger permeability of water through a piece of pig's bladder which covered a jar with spirits of wine. Semi-permeability was first observed here (A. G. T. Fane et al., 2011).

In earlier days of membrane technology, the scientists investigated the permeability of membranes which were of animal origin, such as bladders of pigs, cattle, fish etc. Later at 1907, scientist Bechold came up with an idea of making nitrocellulose membrane. These membranes were of graded pore size, which was determined by bubble test. Microporous collodion membranes (1920) were developed by Elford, Zsigmondy, Bachmann and Ferry. Microporous collodion membranes were commercially available from 1930s. In the next 20 years, this microfiltration technology was expanded to other polymers such as cellulose acetate. Microfiltration membranes were used significantly in a large scale at times of the World War II to purify water meant for drinking for soldiers. Kolf and Berk, 1945 developed artificial kidney in Netherlands for the first time. It took twenty more years for this technology to get perfected. This is one of the most significant life-saving medical methodologies till date. The discovery of reverse osmosis membrane by Loeb and Sourirajan in 1960, paved a way for the membrane technology to get transferred from labs to industry

Copyright (C) 2021. The Author(s). Published by AIJR Publisher.

This is an open access article under Creative Commons Attribution-NonCommercial 4.0 International (CC BY-NC 4.0) license, which permits any non-commercial use, distribution, adaptation, and reproduction in any medium, as long as the original work is properly cited. 
i.e., the RO technology got commercialized and it enabled the scope for the then new technologies like ultrafiltration, nanofiltration and electrodialysis.

There are two important reasons for the growth in the interest of membrane separation processes. First, the ability to produce selective, high flux, essentially defect free membranes on a large scale. Second, the ability to compactly construct these membranes into high-surface-area, low-cost membrane modules.

Membranes can be classified according to their pore size, type of material used, based on state of matter, isotropic or anisotropic etc. Isotropic membranes may be non-porous or microporous. Anisotropic membranes may be separation membranes, interfacial polymerization membranes, solution coated composite membranes, etc. according to the type of material used, the membranes may be made up of metal, ceramic, zeolite, carbon, microporous glass or of mixed matrix. Liquid membranes exist too. Membranes can be of hollow fiber type.

According to the pore size and finding significant applications in the dairy and food industry, membranes are classified as ultrafiltration membrane, reverse osmosis membrane, nano filtration membrane and microfiltration membrane. Large areas of membrane need to be packed efficiently for economical industrial use. this package is called membrane module. The most popular membrane modules are plate and frame modules, tubular modules, spiral wound modules, hollow fiber modules, vibrating and rotating modules submerged membranes for microfiltration/membrane bioreactors and membrane contactors and counterflow sweep modules. The selection of suitable module design depends on the cost, type of separation, type of feed used, availability in large scale etc. Membrane processes offer several advantages to the food industry such as gentle treatment of the product at ambient temperature and thus often offer a substantial improvement in quality. Low energy consumption, simultaneous fractionation and concentration, increased yield and simple operating mechanisms are other advantages (Tragardh, 1991).

\section{Membrane as an Alternative Process}

Milk is a system of suspended particles and soluble molecules of different sizes and charges. The largest particles present in milk naturally is the milk fat, having a size of $1-15 \mu \mathrm{m}$ diameter (average $3.5 \mu \mathrm{m}$ ) in nonhomogenized form. The somatic cells, bacterial spores etc are either in similar size or greater than milk fat. The somatic cells as well as the bacterial spores can be separated from milk by bactofugation process. Alternatively, microfiltration with membrane of pore size 1.4 - 1.8 microns. Microfiltration is a pressure and concentration driven membrane process.

Similarly, instead of heat concentration of traditional Indian dairy products, reverse osmosis can be used to remove excess water/moisture content. Concentration of skim milk can be done without heating. Recovery of certain components like minerals in milk is done traditionally by precipitating them. But membrane processes like reverse osmosis enables the isolation and concentration of minerals without chemical precipitation. In edible oil industry, dewaxing, degumming, deacidification, bleaching etc can be carried out by membrane processes instead of gravimetric and mechanical methods.

\section{Applications of Membrane Technology in Dairy Industry}

\subsection{Cold pasteurization/ Sterilization}

Conventional pasteurization uses heat as a tool for eliminating the active microbial count in milk. Milk is heated to $72^{\circ} \mathrm{C}$ and held at that temperature for 15 seconds. Instead, microfiltration technique can be used to perform cold pasteurization. As the name suggests, cold pasteurization is an alternative way to reduce the microbial load in the milk without heating. Microporous membrane filters are used in this method and most bacteria and yeast are retained (removed). Olesen and Jensen (1989) of Danish Dairy Research Institute studied and performed sterilization of milk using microfiltration technology experiment on milk and obtained $99.99 \%$ reduction in total bacterial count and 99.98\% reduction in Bacillus cereus spores. . Madaeni et al., 2011 studied microfiltration mechanism for both whole milk and skim milk. They used PVDF (Polyvinylidene Fluoride) MF membrane and obtained 99.5\% efficiency in removal of bacteria and spores. Increased fat affected the flux, due to layer formation on the membrane within short time. 
Jasper Shekin J, Extsv. Rev.; Vol. 1, Issue 1, pp: 39-48, 2021

Somatic cells count can be decreased in ovine (sheep) milk by the process of microfiltration using ceramic membrane of $1.4 \mu \mathrm{m}$ at $50^{\circ} \mathrm{C}$ significantly. Panopoulos et al., 2020 found that this microfitration process can be alternatively used as pre-treatment for preparing cheese milk.

In 2019, a study was conducted to increase the shelf life of skim milk by combining both HTST pasteurization and cold microfiltration. Cold micro filtration of raw skim milk was held at $6 \pm 1^{\circ} \mathrm{C}$ using a ceramic membrane of $1.4 \mu \mathrm{m}$ pore size at the pressure of $75.8 \mathrm{kPa}$. The raw milk sample processed by HTST pasteurization method alone, showed reduction of bacterial load up to $\sim 2 \log$. the milk sample that underwent both MF and HTST showed $\sim 4 \log$ reduction in bacterial load and had a satisfiable shelf life for 92 days at 6 . But this sample's proteolytic shelf life was limited by plasmin activity, which can be solved by increasing the heating temperature to $85^{\circ} \mathrm{C}$. (Wang et al., 2019)

Commercially produced pasteurized skim milk had a shelf of 66 days when stored at $6.1^{\circ} \mathrm{C}$ (Total bacterial count of $20,000 \mathrm{cfu} / \mathrm{ml}$ is considered as the end of shelf life). With the combination of both microfiltration as well as conventional pasteurization, shelf life of upto 92 days was achieved at storage temperature $4.2^{\circ} \mathrm{C}$ (Elwell \& Barbano, 2006)

\subsection{UHT Milk Processing}

In UHT milk, gelation or sedimentation is a major issue during storge. In most cases, gelation is the main reason for less shelf life. In 2018, a study was conducted by Incecco and co-workers to study the effects of microfiltration and double homogenization in maintaining the stability during extended shelf life. Microfiltration helped in the delaying of the formation of gel and sediments and also, slowed down the proteolysis in case of peptide accumulation. (D'Incecco et al., 2018)

\subsection{Milk Fat Recovery and Separation}

Conventionally, milk fat is separated by cream separators. Cream separators use centrifugal force to separate the light milk fat from heavier skim milk. Instead microfiltration ceramic membrane of pore size 1.4 microns is used to separate fat molecules from milk. Jukkola et al., (2016) performed microfiltration of milk using membrane of pore diameter $1.4 \mu \mathrm{m}$ and $0.005 \mathrm{~m}^{2}$ filtration surface area. The fat content of the retentate slightly decreased during filtration, due to the fact that milk fat globules have a wide range of particle size approximately from 0.2 to $15 \mu \mathrm{m}$. Reduction in protein content was $88 \%$ and retention of fat was $97 \%$

\subsection{Milk Concentration}

Milk has approximately $87 \%$ of water by nature. It needs to be concentrated for making various milk products. Milk concentration is usually done by either heating in flame or heating using steam infusion technique. Alternatively, milk can be concentrated to a lower level of moisture content by using RO membrane. We know that $\mathrm{RO}$ membrane retains almost all type of molecules except water mainly due to its average pore size of 0.0005 microns.

Arend et al. (2019), performed the concentration of pasteurized skim milk using polyamide RO membrane with a spiral configuration and filtration area of $5.7 \mathrm{~m}^{2}$. Temperature of $20 \pm 5^{\circ} \mathrm{C}$ and 20 bar pressure was maintained in the process. Protein content of skim milk was retained $100 \%$ while lactose and lipid had $99.97 \%$ and $98.47 \%$ retention, respectively.

MPC stands for milk protein concentrates. MPCs have the casein-whey protein ratio same as that of milk. MPCs of protein concentration of $>80 \%$ on dry basis was prepared by ultrafiltration and constant-volume diafiltration. Skim milk was subjected to ultrafiltration which removes water, lactose, peptides and other solutes partially. Polyether sulfone spiral-wound UF membrane was used with MWCO (Molecular Weight Cut-Off) $10 \mathrm{kDa}$ and $50 \mathrm{kDa}$. UF membrane of MWCO $10 \mathrm{kDa}$ showed better protein retention (GavazziApril et al., 2018). MPC can be prepared using wide-pore negative charge UF membranes. Six-fold concentration was done and followed by diafiltration. Conventionally $30 \mathrm{kDa}$ membranes are used in this process. But, when the negatively charged $100 \mathrm{kDa}$ membrane was used, four times more permeate was recovered. It is based on the fact that when a negative charge is placed on the membrane, the proteins gets 
repelled and this particular type of UF is not just a size-based sieving process (Arunkumar and Etzel, 2018). MPCs prepared with and without the step of diafiltration were studied for their heat stability just after preparation (fresh samples). One sample was tested for HCT directly after UF and another sample was subjected to diafiltration with water. Non-diafiltered concentrates showed HCT time of 30 mins while diafiltered MPC showed 50 mins stability against coagulation. This proves that diafiltration is an essential step after UF (Renhe et al., 2019).

A surface-active solution is obtained as permeate of UF process. Surface active solution is defined as the solution whose surface tension decreases upon compression. Real Hernandez \& Jimenez-Flores (2019), found that the permeate of skim milk was also surface-active, may be due to trace proteins and peptides present in the concentrated protein. It was found that ultrafiltration and solvent induced emulsions can be used to make milk into a Langmuir trough subphase, and the surfactants can be removed from milk without adding foreign substances. Antioxidant activity of UF permeate of skim milk (10 kDa hollow fibre membrane cartridge) was studied by Lamothe et al. (2019), using simulated digestion. In skim milk, the antioxidant activity was found to be in ascending order: buccal, gastric and intestinal antioxidant activity respectively. Ramchandran et al. (2017), found that the solubility and heat stability of MPCs obtained by ultrafiltration process can be increased by the addition of calcium chelators. Acid gelation of concentrated skim milk characterized by casein micelles had negative effect during acidification when treated by DF compared to the concentrated milk treated by UF even though the protein concentration is same (Li \& Corredig, 2020).

\subsection{Cheese Making}

Cheese can be prepared alternatively by ultrafiltration. Ultrafiltration of milk concentrates the components like milk fat, proteins and insoluble salts primely and removes water, soluble salts and Non-Protein Nitrogen (NPN). Also, UF enables the undenatured proteins to remain undenatured even after concentration. Kosikowski, 1974 studied the effect of ultrafiltration in cheese making compared to the usual process. $0.03 \mu \mathrm{m}$ pore sized membrane was used under a pressure of $1-50 \mathrm{~kg} / \mathrm{cm}^{2}$. After obtaining the retentate, lactic acid culture was introduced followed by milk fat, colour, other microorganisms and rennet. Two important observations were done. First, the retentate even after adding milk fat, stayed stable till renneting. Second, 75 to $80 \%$ less rennet was enough for coagulation which was rapid as normal.

The concentrated milk meant for cheese making can be prepared by both $\mathrm{RO}$ and UF process. In a study, initially the $\mathrm{pH}$ of both the $\mathrm{RO}$ concentrate and the UF concentrate was 6.5. Adjustment of $\mathrm{pH}$ in UF concentrate did not have much effect on the UF concentrate but improved the rennet-gelation behaviour of $\mathrm{RO}$ concentrated cheese milk. This must be due to the presence of calcium, magnesium and potassium content dissolved in the $\mathrm{RO}$ concentrate. At $\mathrm{pH}$ 6.3, $\mathrm{RO}$ concentrate had similar properties to UF concentrate of pH 6.5 (Lauzin et al., 2019).

An alternate process for making low fat cheddar cheese was developed by Amelia and co-workers, 2013. This LFCC (Low Fat Cheddar Cheese) is a combination of fat removed RFCC (Reduced Fat Cheddar Cheese) and MCC (Micellar Casein Concentrate) produced by the ultrafiltration of skim milk. LFCC with $50 \%$ and 75\% RFCC were successfully produced (Amelia et al., 2013). Fortification of cheese milk with ultrafiltration retentate of skim milk combined with high-hydrostatic pressure treatment helped in the production of low sodium cheddar cheese with significantly lower bitterness after 1 month ripening when compared to other samples of low sodium cheddar cheeses that underwent no UF retentate fortification but had high-hydrostatic pressure treatment in processing alone and also the conventional LFCC (Ozturk et al., 2015). In low and reduced fat millet curd direct salted gouda cheese, two variants were produced and studied for understanding the flavour and textural quality: cheese produced from cheese milk which is lactose standardised using ultrafiltration technique and cheese in which whey solution is diluted by adding water. It was found that when lactose content was increased i.e., lactose to casein ratio is modified, low fat gouda cheese adds lower acidity and softer texture (Ibáñez et al., 2020). 
Jasper Shekin J, Extsv. Rev.; Vol. 1, Issue 1, pp: 39-48, 2021

The idea of concentrating milk meant for cheese making by reverse osmosis in the farms will enable the decrease in transportation cost of milk, less energy consumption in cheese making and will be preferred by the cheese manufacturer (Taivosalo et al., 2019). The lactose content in cheese made from reverse osmosis concentrate and ultrafiltration concentrate differs from each other. Reverse Osmosis concentrate cheese showed an extra yield of 7\% when compared to cheese made from UF concentrate. The time taken for curd formation was superior in UF compared to RO. the cheese moisture was about 3\% more in RO type. Demineralization may be required in RO concentrate prepared cheese to improve its quality (Lauzin et al., 2020).

\subsection{Traditional Dairy Products}

Chakek and Shrikhand of excellent sensory attributes can be made with UF as one if the steps of production. Initially, skim milk is fermented with yogurt culture and heated to $60^{\circ} \mathrm{C}$ for 5 mins with continuous agitation and ultrafiltered to reach about $16.60 \%$ TS concentration. Whey is removed using muslin cloth to get chakek. Chakka is then kneaded with $70 \%$ fat cream and sugar to prepare Shrikhand of smooth consistency. UF process resulted in nil fat loss in whey and $20.70 \%$ extra recovery of total solids in chakka. Paneer is a heat-acid coagulated traditional milk product. Typically, paneer is white in colour, has a spongy body, closeknit texture, has sweetish-acidic nutty flavour etc. Traditional paneer manufacture involves heat acid coagulation of standardized milk followed by the pressing of the coagulum. This manufacturing method involves more labour and energy requirement, and the product may have more chances of contamination during processing. Ultrafiltration can be used alternatively after standardization and heating, whereby lactose, water and some minerals are removed. UF of milk and the removal of permeate will give similar results to the removal of whey by coagulation in conventional method of paneer making. The concentrated retentate, which has about $40 \% \mathrm{TS}$, is cold acidified to obtain the desired $\mathrm{pH}$. Till this point, the product is flowable and can be easily dispensed in containers with automatic dispensing machines. The filled containers are then subjected to texturization by microwave heating or any similar process. The microwaving process may be either batch type or continuous. The final product will have typical characteristics of normal paneer.

Similarly, in khoa making, RO process can be used. Using RO membranes, firstly the milk is concentrated from around $13 \%$ TS to 30\% TS. Then, this concentrated milk is heat desiccated to make khoa. When using RO for removing water content of milk, energy can be saved especially in large processing batches and the resultant khoa made in this method had a highly satisfactory quality. (Dharam Pal, 2005)

\subsection{Powder Formulation}

Lactose-free dairy products are in a growing demand due to lactose intolerance. Conventionally, low lactose milk powder is prepared by enzymatic method. Alternatively, three membrane technologies namely, Ultrafiltration, Electrodialysis and Nanofiltration are used combinedly to avoid enzymatic process and introduce a novel green technology for making low lactose milk powder. In this process, initially large molecules like fat and protein are retained by ultrafiltration. Mineral salts are readded into milk by electrodialysis and finally lactose is recovered by nanofiltration. Thus, low-lactose milk powder was produces which had a lactose content of less than $0.2 \%$. On the other hand, lactose powder of high purity $(95.7 \%)$ was obtained from NF concentrate (H. Zhang et al., 2020). Dairy whitener can be prepared from $\mathrm{UF}$ retentate. UF process was carried out at $50^{\circ} \mathrm{C} 5$ fold, $\mathrm{ZrO}_{2}$ membrane material was used, membrane surface area $1.68 \mathrm{~m}^{2}$ and membrane molecular weight cut off $50 \mathrm{kDa}$. The resultant dairy whitener (powder) had high protein, high calcium and low lactose compared to the market available dairy whiteners and had good solubility index, wettability, dispersibility and whitening ability (Khatkar \& Gupta, 2014).

\subsection{Ice-Cream and Frozen Desserts}

Formulation and preparation of ice-cream mix is a vital process in ice-cream making. In conventional icecream mix making method, milk and cream of standard fat and SNF (Solids-Not-Fat) values are mixed 
initially. Stabilizer/emulsifier blend is added to make the mix stable. To meet the minimum standards of SNF and protein of ice-cream (according to FSSAI), skim milk powder is added to the mix in a calculated amount. Each mix component has varying molecular weight and size which paves a way for the possibility of membrane processes as alternative method for the standardization of mix. Instead of adding SMP, milk can be concentrated by either of the two methods, heating with vacuum evaporators or using $\mathrm{RO}$ membrane technique for removing water. Garcia et al. (1989), studied the effects of using UF and RO separately for concentration of milk in ice-cream making. The main advantage in this method is that RO process is more efficient than vacuum evaporation.

\subsection{Fermented Dairy Products}

UF, NF and RO have different abilities to separate specific components of milk. The use of membrane processes in the manufacture of fermented dairy products showed improved the control of quality attributes like consistency, post-processing acidification and extent of syneresis. Traditionally, Greek yoghurt was strained by cheese cloth during processing to remove the whey. Alternatively, and in betterment, this straining is replaced by ultrafiltration technique. In making of Greek yoghurt, it was found that UF process before fermentation of milk helped in better valorization and also avoided the dumping of acid rich whey which will cause environmental effects, than the UF process done after fermentation of milk (Valencia et al., 2018). However, one should be aware that the type of membrane used may cause compositional changes in the final product. (Rosenberg, 1995)

\subsection{Waste Valorization}

Membrane bioreactors with filamentous fungi combinedly can be used for waste valorization of expired milk. As per reports, 29 million tons of milk gets expired and end as waste in Europe. In 2000, a research was conducted for this waste valorization using the integration of membrane bioreactors and edible filamentous fungi namely, Aspergillus oryzae and Neurospora intermedia. The membrane process used was microfiltration. Milk was diluted $70 \%$ and both the fungi were used to consume lactose prior to MF. The developed approach proved effective in increasing the value of non-sterile unusable milk. A balance was achieved between consumption of bacterial growth-derived acids, consequent $\mathrm{pH}$, and fungal enzymatic activities (Belafi-Bako et al., 2000).

\subsection{Component Recovery}

Milk and milk products are nutritious due to its composition. They are good sources of protein, milk fat, vitamins, minerals, lactose etc. In many milk products lactose gets wasted as dairy effluents. The dairy effluents both cause pollution and loss of value, when lactose is wasted along. In making of coagulated dairy products, the wastage of lactose is high. Lactose has a high value of nutrition and acts as an ingredient in many dairy and non-dairy based food applications. The common composition of dairy effluents is solids $7 \%$, WP $3 \%$, fats $1 \%$ and lactose 3\%. For the recovery of lactose, PSF (Polysulfone) membrane-based ultrafiltration process can be used. PSF is mainly used due to its chemical, dimensional and thermal stability, its resistance to mineral acids, surfactants, hydrocarbon oils, electrolytes and oxidizing agents, hydrophobicity and high strength and stiffness. Results of this experiment shows that $96 \%$ of major components in dairy effluents was recovered (Ghatawat et al., 2019).

Cheese whey can be subjected to ultrafiltration that utilizes polyether sulfone membrane off molecular weight cut off $10 \mathrm{kDa}$ to produce whey protein concentrates or whey protein isolates. It is essential to isolate/concentrate these protein products to obtain products of greater value like $\alpha$-Lactalbumin. Using cheese whey as feed, $\alpha$-Lactalbumin enriched WPC of $62 \%$ concentration was achieved (Marella et al., 2013). Wen-qiong et al., 2017 found that cheese whey catalyzed by TG (transglutaminase) enzyme showed an increased recovery rate of whey proteins upto $15-20 \%$, decreased lactose rejection rate to around $10 \%$, increase in relative permeate flux to $30-40 \%$ at $\mathrm{pH} 5.0,40 \mathrm{U} / \mathrm{g}$ enzyme concentration and reaction time of 
Jasper Shekin J, Extsv. Rev.; Vol. 1, Issue 1, pp: 39-48, 2021

60 minutes. They have also found that the total membrane resistance and cake resistance where decreased due to enzyme catalysis at $\mathrm{pH} 5.0$

\section{Applications of Membrane Technology in Food Industry}

\subsection{Fruit and Vegetable Juice and Beverage Industry}

Concentration of fruit and vegetable juices are conventionally achieved by heating by vacuum evaporation. Alternatively, membrane processes can be used to concentrate them. The water content of juices are very high $(75 \%$ to $90 \%)$. Economy is achieved when concentrated juices are transported rather than transporting as such. Microfiltration can be used to remove microorganisms and suspended solids, cell walls, fibers, starch and granules. UF can retain polysaccharides, proteins and tannins. NF can retain sugars, organic acids, polyphenols, aromatic components etc. RO can be used to lessen the water content and also be able to retain certain salts depending upon the operating pressure (10-100 bar) (Conidi et al., 2020; Echavarría et al., 2011).

In beer industry, microfiltration is performed to recover beer with surplus yeast. Reverse osmosis is done to remove the alcohol content in Beer. This process is called dealcoholization. After the processes of recovery of yeast by microfiltration and reducing the alcohol content by reverse osmosis, clarification is done by plate and frame cross floor microfiltration membrane which removes bacteria and spores. NF and MF can be done simultaneously to provide clarification and sterilization in one stage to reduce cost and time of operation (Peyravi et al., 2019). Similarly, wine can be clarified by using polyether sulfone, cellulose acetate, cellulose mixed ester, polypropylene, and nylon ultrafiltration membranes. Different pore diameters and membrane type decides the permeate flux and they are chosen according to the need. Rejuvenation of wine i.e., development of negative aroma can be removed by using RO membrane (Peyravi et al., 2019).

Imidacloprid and acetamiprid are two pesticides used for the protection of tea leaves during growth. These chemicals stay in tea leaves and continue in tea if left unchecked. Microfiltration enabled the removal of imidacloprid and acetamiprid to a great extent $(79.7 \%$ for imidacloprid and $81.9 \%$ acetamiprid) (Y. Zhang et al., 2015).

Reverse osmosis technique can be used for both concentrating the fruit juice by removal of water and also improves the antioxidant properties of fruit juices. The TSS content, total acidity, colour etc increases in proportion similar to the unprocessed fruit juice. To the contrary, the antioxidant capacity of apple, blueberry and cranberry juice was increased $40 \%, 34 \%$ and 30\% respectively. LDL (Low Density Lipoprotein) oxidation pause inhibited up to $41 \%$ and $45 \%$ in blueberry and cranberry juices respectively. Thus, reverse osmosis helps in improving health by consuming these antioxidant rich fruit juices. (Gunathilake et al., 2014)

\subsection{Meat Industry}

Meat industry comprises of poultry, fisheries, cattle etc. The water used for processing of meat and meat products is drained as wastewater. This wastewater contains fat, protein, ash (minerals), sodium which can be separated economically using membrane processes. The filtration techniques MF, UF and VMD (Vacuum Membrane Distillation) were used in a series to treat the poultry processing water by Białas et al. (2014) .

Angiotensin-I-converting enzyme (ACE) inhibitory peptides is known to be effective against high blood pressure/hypertension. Two novel ACE inhibitory peptides, His-Leu-His-Thr, HLHT and Gly-Trp-Ala, GWA were isolated from Pearl oyster meat protein hydrolysate, in addition with alkaline protease by ultrafiltration, in a polyethylene glycol methyl ether modified immobilised metal iron Infinity medium and reverse phase HPLC. These peptides can be used as ingredients of functional foods against hypertension (Liu et al., 2019).

a137-141 (653 Da, TSKYR) is a peptide of interest, which can be used as an ingredient of foods that acts as antimicrobial preservative. This peptide inhibits a large range of microbial growth and delays rancidity in meat. So, if it is available in a large quantity in meat, the meat will have a longer shelf life. Fractionation of 
by-product hydrolysates obtained from meat industry is required to isolate this peptide. EDUF (Electrodialysis with Ultrafiltration) membrane is the technology used in the isolation. The resultant peptide concentration had $50 \%$ of $\alpha 137-141$ in it. This peptide concentrate can also be used as a natural preservative alternatively to synthetic additives (Przybylski et al., 2020).

\subsection{Edible Oil Industry}

Vegetable origin oils are edible, source of non-animal fat, and are healthy when consumed in prescribed amounts. But naturally, vegetable oils are gummy, more acidic to use as food additive, more viscous, waxy etc. So, dewaxing, deacidification, bleaching and degumming are some common procedures used to make the oil more acceptable in the market as well as for good health. These processes are a part of vegetable oil processing. Degumming process of expressed soyabean and rapseed oils can be done by NTGS nonporous membranes, but phospholipid rejection is high and flux rate is too low. Instead UF membranes can be used to overcome these problems. Cellulose acetate membrane is more suitable for rice bran oil degumming, as it gives a high flux rate. Deacidification or neutralization has a great importance in oil processing. If not done, it will lead to loss of oil in the further processing steps. Deacidification is widely done by alkali refining. Cellulose acetate membrane was already used in this step but didn't have a satisfactory result. The challenge of designing a standard membrane process setup for specific oils is still existent (Ladhe \& Krishna Kumar, 2010).

\subsection{Confectionary and Bakery Products}

Confectionary and bakery products do not have considerable direct applications of membrane technology. But as we know, Whey protein isolate (WPI), whey protein concentrate (WPC) and milk protein concentrate (MPC) are added then and there for better nutrition quality in cakes, biscuits, confectionary sweets etc, membrane processes are the most helping process in making WPI, WPC and MPC (Dhineshkumar and Ramasamy, 2017).

\section{Challenges}

- Product quality and productivity gets affected after a period of use mainly due to fouling.

- Membrane processes are not better alternatives for most of the conventional processes. Eg, fat separation in milk.

- Membranes are responsible for greenhouse gas emissions (A. G. Fane, 2011).

- Unavailability of membrane producing industries in a large scale in countries like India.

\section{Conclusion}

Membrane technology is inevitable in our daily life right from clean water production for drinking to advanced food processing methods. the right understanding and knowledge about specific membranes and the feed given, will help in choosing the most suitable membrane process for a particular food/dairy product. proper maintenance of membrane apparatus should be done to prevent any deviation in the quality of the processed food. In contrast to the challenges and limitations of using membrane technology it has advantages like lower system costs and affordability, minimisation of energy demand, can be automated easily because of simpler mechanism, minimizations of nutrient loss etc. At present and in the near future, membranes of better quality and easier maintenance from as of now are expected to be developed and extensively used

\section{How to Cite this Article:}

J. Shekin J, "Applications of Ultrafiltration, Reverse Osmosis, Nanofiltration, and Microfiltration in Dairy and Food Industry”, Extsv. Rev., vol. 1, no. 1, pp. 39-48, Dec. 2021. 
Jasper Shekin J, Extsv. Rev.; Vol. 1, Issue 1, pp: 39-48, 2021

\section{References}

Amelia, I., Drake, M. A., Nelson, B., \& Barbano, D. M. (2013). A new method for the production of low-fat Cheddar cheese. Journal of Dairy Science, 96(8), 4870-4884. https://doi.org/10.3168/jds.2012-6542

Arend, G. D., Castoldi, S. M., Rezzadori, K., Soares, L. S., \& Brião, V. B. (2019). Concentration of skim milk by reverse osmosis: Characterization and flow decline modelling. Brazilian Journal of Food Technology, 22, 1-12. https://doi.org/10.1590/19816723.02819

Arunkumar, A and Etzel M R (2018). Milk Protein Concentration Using Negatively Charged Ultrafiltration Membranes. Foods, 7, 134 : 1-10. https://doi.org/10.3390/foods7090134

Belafi-bak, K., Gubicza, L., \& Mulder, M. (2000). Integration of Membrane Processes into Bioconversions. https://doi.org/10.1007/978-14615-4269-8

Białas, W., Stangierski, J., Konieczny, P. (2014). Protein and water recovery from poultry processing wastewater integrating microfiltration, ultrafiltration and vacuum membrane distillation. International Journal of Environmental Science and Technology, 12(6), 1875-1888. https://doi.org/10.1007/s13762-014-0557-4

Conidi, C., Castro-Muñoz, R., \& Cassano, A. (2020). Membrane-based operations in the fruit juice processing industry: A review. Beverages, 6(1), 1-39. https://doi.org/10.3390/beverages6010018

D’Incecco, P., Rosi, V., Cabassi, G., Hogenboom, J. A., \& Pellegrino, L. (2018). Microfiltration and ultra-high-pressure homogenization for extending the shelf-storage stability of UHT milk. Food Research International, 107(2017), 477-485. https://doi.org/10.1016/j.foodres.2018.02.068

Dharam Pal (2005). Role of Membrane Processing in Traditional Dairy Products. http://ecoursesonline.iasri.res.in/mod/page/view.php?id=6321

Dhineshkumar V, Ramasamy D. (2017). Review on Membrane Technology Applications in Food and Dairy Processing. Journal of Applied Biotechnology \& Bioengineering, 3(5), 399-407. https://doi.org/10.15406/jabb.2017.03.00077

Echavarría, A. P., Torras, C., Pagán, J., Ibarz, A. (2011). Fruit Juice Processing and Membrane Technology Application. Food Engineering Reviews, 3(3-4), 136-158. https://doi.org/10.1007/s12393-011-9042-8

Elwell, M. W., \& Barbano, D. M. (2006). Use of microfiltration to improve fluid milk quality. Journal of Dairy Science, 89, E. Suppl 1, 2030. https://doi.org/10.3168/jds.s0022-0302(06)72361-x

Fane, A. G. (2011). Membranes and the water cycle: challenges and opportunities. Applied Water Science, 1(1-2), 3-9. https://doi.org/10.1007/s13201-011-0002-5

Fane, A. G. T., Wang, R., \& Jia, Y. (2011). Membrane Technology: Past, Present and Future. In Membrane and Desalination Technologies (Vol. 13). Handbook of Environmental Engineering. https://doi.org/10.1007/978-1-59745-278-6

Garcia, A., Medina, B., Verhoek, N., \& Moore, P. (1989). Ice Cream Components Prepared with Ultrafiltration And Reverse Osmosis Membranes. Biotechnology Progress, 5(1), 46-50. https://doi.org/10.1002/btpr.5420050111

Gavazzi-April, C., Benoit, S., Doyen, A., Britten, M., \& Pouliot, Y. (2018). Preparation of milk protein concentrates by ultrafiltration and continuous diafiltration: Effect of process design on overall efficiency. Journal of Dairy Science, 101(11), 9670-9679. https://doi.org/10.3168/jds.2018-14430

Ghatawat, P., Vankar, Y., Dhume, S., Chendake, Y. (2019). Separation and Recovery of Milk Components from Dairy Effluent. International Journal of Engineering Research and Technology (IJERT), 8(06), 884-888. https://doi.org/10.3390/su10061940

Gunathilake, K. D. P. P., Yu, L. J., \& Rupasinghe, H. P. V. (2014). Reverse osmosis as a potential technique to improve antioxidant properties of fruit juices used for functional beverages. Food Chemistry, 148, 335-341. https://doi.org/10.1016/j.foodchem.2013.10.061

Ibáñez R. A., Govindasamy-Lucey, S., Jaeggi, J. J., Johnson, M. E., McSweeney, P. L. H., \& Lucey, J. A. (2020). Low- and reduced-fat milled curd, direct-salted Gouda cheese: Comparison of lactose standardization of cheesemilk and whey dilution techniques. Journal of Dairy Science, 103(2), 1175-1192. https://doi.org/10.3168/jds.2019-17292

Jukkola, A., Partanen, R., Rojas, O. J., \& Heino, A. (2016). Separation of milk fat globules via microfiltration: Effect of diafiltration media and opportunities for stream valorization. Journal of Dairy Science, 99 (11), 1-11. https://doi.org/10.3168/jds.2016-11422

Khatkar, S. K., \& Gupta, V. K. (2014). Physicochemical and functional quality attributes of dairy whitener prepared from ultrafiltration process. Journal of Food Processing and Preservation, 38(3), 1145-1154. https://doi.org/10.1111/jfpp.12074

Kosikowski, F. v. (1974). Cheesemaking by Ultrafiltration. Journal of Dairy Science, 57(4), 488-491. https://doi.org/10.3168/jds.S00220302(74)84920-9

Ladhe, A. R., \& Krishna Kumar, N. S. (2010). Application of Membrane Technology in Vegetable Oil Processing (Chapter 5). In Membrane Technology (First Edit). Elsevier Ltd. https://doi.org/10.1016/B978-1-85617-632-3.00005-7

Lamothe, S., Guérette, C., Dion, F., Sabik, H., \& Britten, M. (2019). Antioxidant activity of milk and polyphenol-rich beverages during simulated gastrointestinal digestion of linseed oil emulsions. Food Research International, 122, 149-156. https://doi.org/10.1016/j.foodres.2019.03.068

Lauzin, A., Bérubé, A., Britten, M., \& Pouliot, Y. (2019). Effect of pH adjustment on the composition and rennet-gelation properties of milk concentrates made from ultrafiltration and reverse osmosis. Journal of Dairy Science. 102(5), 3939-3946. https://doi.org/10.3168/jds.2018-15902

Lauzin, A., Pouliot, Y., \& Britten, M. (2020). Understanding the differences in cheese-making properties between reverse osmosis and ultrafiltration concentrates. Journal of Dairy Science. 103(1), 201-209. https://doi.org/10.3168/jds.2019-16542

Li, Y., \& Corredig, M. (2020). Acid induced gelation behavior of skim milk concentrated by membrane filtration. Journal of Texture Studies, 51(1), 101-110. https://doi.org/10.1111/jtxs.12492

Liu, P., Lan, X., Yaseen, M., Wu, S., Feng, X., Zhou, L., Sun, J., Liao, A., Liao, D., \& Sun, L. (2019). Purification, Characterization and Evaluation of Inhibitory Mechanism of ACE Inhibitory Peptides from Pearl Oyster (Pinctada fucata martensii) Meat Protein Hydrolysate. Marine drugs. 17(8), 463(1-13). https://doi.org/10.3390/md17080463

Madaeni, S. S., Yasemi, M., \& Delpisheh, A. (2011). Milk sterilization using membranes. Journal of Food Process Engineering, 34(4), 10711085. https://doi.org/10.1111/j.1745-4530.2009.00532.x 
Marella, C., Muthukumarappan, K., Metzger, L. E. (2013). Application of Membrane Separation Technology for Developing Novel Dairy Food Ingredients. Journal of Food Processing \& Technology, 04(09). https://doi.org/10.4172/2157-7110.1000269

Olesen, N., \& Jensen, F. (1989). Microfiltration. The influence of operation parameters on the process. Milchwissenschaft-milk Science International, 44, 476-479. http://pascal-francis.inist.fr/vibad/index.php?action=getRecordDetail\&idt=7305906

Ozturk, M., Govindasamy-Lucey, S., Jaeggi, J. J., Johnson, M. E., \& Lucey, J. A. (2015). Low-sodium Cheddar cheese: Effect of fortification of cheese milk with ultrafiltration retentate and high-hydrostatic pressure treatment of cheese. Journal of Dairy Science, 98(10), 67136726. https://doi.org/10.3168/jds.2015-9549

Panopoulos, G., Moatsou, G., Psychogyiopoulou, C., \& Moschopoulou, E. (2020). Microfiltration of Ovine and Bovine Milk: Effect on Microbial Counts and Biochemical Characteristics. Foods, 9(3), 284. https://doi.org/10.3390/foods9030284

Peyravi, M., Jahanshahi, M., \& Banafti, S. (2019). Application of membrane technology in beverage production and safety. In Safety Issues in Beverage Production: Volume 18: The Science of Beverages (2020. 271-308). Elsevier Inc. https://doi.org/10.1016/B978-0-12$816679-6.00008-5$

Przybylski, R., Bazinet, L., Firdaous, L., Kouach, M., Goossens, J.-F., Dhulster, P., \& Nedjar-Arroume, N. (2020). Electroseparation of Slaughterhouse By-Product: Antimicrobial Peptide Enrichment by $\mathrm{pH}$ Modification. Membranes. 10(90). 1-14. https://doi.org/10.3390/membranes10050090

Ramchandran, L., Luo, X. X., \& Vasiljevic, T. (2017). Effect of chelators on functionality of milk protein concentrates obtained by ultrafiltration at a constant $\mathrm{pH}$ and temperature. Journal of Dairy Research, 84(4), 471-478. https://doi.org/10.1017/S0022029917000528

Real Hernandez, L., \& Jimenez-Flores, R. (2019). Preparation of Non-Surface-Active Langmuir Trough Subphases from Milk. ACS Omega, 2019(4), 14920-14927. https://doi.org/10.1021/acsomega.9b01659

Renhe, I. R. T., Zhao, Z., \& Corredig, M. (2019). A comparison of the heat stability of fresh milk protein concentrates obtained by microfiltration, ultrafiltration and diafiltration. Journal of Dairy Research, 86(3), 347-353. https://doi.org/10.1017/S0022029919000426

Rosenberg, M. (1995). Current and future applications for membrane processes in the dairy industry. Trends in Food Science and Technology, 6(1), 12-19. https://doi.org/10.1016/S0924-2244(00)88912-8

Taivosalo, A., Kriščiunaite, T., Stulova, I., Part, N., Rosend, J., Sõrmus, A., \& Vilu, R. (2019). Ripening of Hard Cheese Produced from Milk Concentrated by Reverse Osmosis. Foods, 8(165), 1-19. https://doi.org/10.3390/foods8050165

Tragardh, G. (1991). Membrane Applications in the Food Industry. Polymer Journal, 23(5), 521-529. https://doi.org/10.1295/polymj.23.521

Valencia, A. P., Doyen, A., Benoit, S., Margni, M., \& Pouliot, Y. (2018). Effect of ultrafiltration of milk prior to fermentation on mass balance and process efficiency in Greek-style yogurt manufacture. Foods, 7(9), 144. https://doi.org/10.3390/foods7090144

Wang, D., Fritsch, J., \& Moraru, C. I. (2019). Shelf life and quality of skim milk processed by cold microfiltration with a 1.4- $\mu$ m pore size membrane, with or without heat treatment. Journal of Dairy Science, 102(10), 8798-8806. https://doi.org/10.3168/jds.2018-16050

Wen-qiong, W., Lan-wei, Z., Xue, H., \& Yi, L. (2017). Cheese whey protein recovery by ultrafiltration through transglutaminase (TG) catalysis whey protein cross-linking. Food Chemistry, 215, 31-40. https://doi.org/10.1016/j.foodchem.2016.07.057

Zhang, H., Tao, Y., He, Y., Pan, J., Yang, K., Shen, J., \& Gao, C. (2020). Preparation of Low-Lactose Milk Powder by Coupling Membrane Technology. ACS Omega, 5(15), 8543-8550. https://doi.org/10.1021/acsomega.9b04252

Zhang, Y., Lu, H., Wang, B., Zhang, Z., Lin, X., Chen, Z., \& Li, B. (2015). Removal of imidacloprid and acetamiprid from tea infusions by microfiltration membrane. International Journal of Food Science and Technology, 50(6), 1397-1404. https://doi.org/10.1111/ijfs.12785

Publish your research article in AIJR journals-

$\checkmark \quad$ Online Submission and Tracking

$\checkmark$ Peer-Reviewed

$\checkmark \quad$ Rapid decision

$\checkmark \quad$ Immediate Publication after acceptance

$\checkmark \quad$ Articles freely available online

$\checkmark \quad$ Retain full copyright of your article.

Submit your article at journals.aijr.org
Publish your books with AIJR publisher-

Publish with ISBN and DOI.

Publish Thesis/Dissertation as Monograph.

Publish Book Monograph

Publish Edited Volume/ Book.

Publish Conference Proceedings

Retain full copyright of your books.

Submit your manuscript at books.aijr.org 